\title{
Commentary High mobility group box-1 protein - one step closer to the clinic?
} Tom Eirik Mollnes ${ }^{1,2}$

\author{
${ }^{1}$ Institute of Immunology, University of Oslo, Rikshospitalet University Hospital, Sognsvannsv. 20, NO-0027 Oslo, Norway \\ 2 University of Tromsø, Department of Laboratory Medicine, Nordland Hospital, Prinsensgt. 164, NO-8092 Bodø, Norway
}

Corresponding author: Tom Eirik Mollnes, t.e.mollnes@medisin.uio.no

Published: 17 July 2008

This article is online at http://ccforum.com/content/12/4/168

(C) 2008 BioMed Central Ltd

Critical Care 2008, 12:168 (doi:10.1186/cc6944)

See related research by Kornblit et al., http://ccforum.com/content/12/3/R83

\begin{abstract}
High mobility group box (HMGB)1, originally described as a nuclear protein that binds to and modifies DNA, is now regarded as a central mediator of inflammation by acting as a cytokine. HMGB1 is postulated to be particularly important as a late acting mediator of lethal septicaemia in mice. Furthermore, it has been suggested that HMGB1 plays a role in clinical conditions such as autoimmunity, acute ischaemia-reperfusion injury, cardiovascular disease and cancer. HMGB1 has emerged as a candidate for therapeutic intervention in various disease conditions. However, further basic and clinical studies are warranted to confirm the roles played by HMGB1 in clinical medicine.
\end{abstract}

In the previous issue of Critical Care, Kornblit and coworkers [1] presented novel data on a possible relation between polymorphisms in the HMGB1 gene (which encodes the high mobility group box [HMGB]1 protein) and clinical outcome in patients with systemic inflammatory response syndrome. Specifically, they identified significant associations between a promoter variant $(-1377 \mathrm{del} A)$ and overall late survival and between an exon 4 variant $(982 \mathrm{C}>\mathrm{T})$ and early mortality due to infection. The latter was also associated with several clinical parameters related to disease severity. These data are of particular interest in the light of recent research suggesting a pathogenetic role for HMGB1 in experimental sepsis.

Definite strengths of the study are the reliable gene technology methods they used, the prospective design of the study, and the authors' experience in handling genetic data in complex clinical settings. However, clinical studies will always be hampered by a risk for inaccurate diagnosis, despite the existence of diagnostic criteria. This is particularly true in patients who have a complex disease pattern and in disorders such as systemic inflammatory response syndrome, which have a number of underlying causes. Thus, the data presented must be confirmed in larger studies and by other groups before they can be used clinically to inform efforts to predict outcome or select patients for specific treatments.

HMGB1 is constitutively expressed in the nuclei of eukaryotic cells. It belongs to a family of high mobility group nuclear proteins that were described in the 1970s as gene regulators that bind to and change the configuration of DNA [2,3]. It later became evident that HMGB1 is actively secreted from cells, has cytokine activities and is a late mediator of endotoxin lethality in mice [4]. Passive release of HMGB1 from necrotic cells also triggers inflammation [5]. Receptors for HMGB1 signalling include RAGE (receptor for advanced glycation end-products) and Toll-like receptors. HMGB1 is a central actor in the inflammatory network because it is induced by a number of cytokines and itself induces a series of inflammatory reactions. More than 1,500 papers on HMGB1 have been published. In recent years a substantial number of studies focused on the role played by HMGB1 in pathophysiology and disease (for reviews see [6-9]).

Attempts have been made to attenuate HMGB1-mediated effects in experimental sepsis, including anti-HMGB1antibodies [4], HMGB1 antagonists [10] and neuropeptides [11]. Inhibition of HMGB1 not only prevented development of lethal sepsis in rodents but also reversed established sepsis, underscoring the delayed function and potential importance of HMGB1 in this condition. However, the road from animal models to clinic is unpredictable. Although HMGB1 was found to correlate with development of disseminated intravascular coagulation [12], a study using two different HMGB1 assays [13] demonstrated persistently increased levels of HMGB1 in patients with sepsis, but surprisingly the investigators found that HMGB1 measured using one of the assays was lower in nonsurvivors than in survivors. This is also interesting in light of the study reported by Kornblit and

$\mathrm{HMGB}=$ high mobility group box; RAGE = advanced glycation end-products. 
coworkers [1], because the HMGB1 exon 4 variant $(982 \mathrm{C}>\mathrm{T})$, which was found to be associated with disease severity and death due to infection, was also associated with low HMGB1 serum concentrations. However, another study did not identify differences in HMGB1 levels between survivors and nonsurvivors with severe sepsis [14]. Thus, traditional lessons must be recalled; experimental data should always be interpreted with caution with respect to their applicability to the human setting, and assays should be carefully validated and compared between different laboratories in order to obtain reliable and consistent data. Thus, the role for HMGB1 as a predictor of clinical sepsis or as a therapeutic target remained to be determined.

Interest in HMGB1 extends far beyond sepsis and systemic inflammatory response. As a pleiotropic cytokine, HMGB1 is involved in inflammation and tissue damage in disease conditions such as autoimmunity, acute ischaemia-reperfusion, cardiovascular disease and cancer. Recently, a causal role for HMGB1 in acute myocardial infarction injury in mice was documented [15]. Interestingly, HMGB1 appeared as soon as 30 minutes after myocardial injury, which contrasts with the late phase pattern seen in sepsis. The pattern of response may therefore depend on the underlying pathophysiology of the condition in question. This will have consequences for possible treatment regimens if it ultimately transpires that HMGB1 is a potential clinical intervention. If it does, then an innumerable number of patients with various common diseases will join the queue for such a treatment. However, historical lessons teach us that there are good reasons to dampen any unrealistic enthusiasm and instead focus on conducting good research, which, step by step, will hopefully yield greater insight into the complex biology of this interesting molecule. Finally, it should be emphasized that although HMGB1 may seem to be the first violinist under certain conditions, it is but one of the players in the inflammatory orchestra.

\section{Competing of interests}

The author declares that they have no competing interests.

\section{References}

1. Kornblit B, Munthe-Fog L, Madsen HO, Strøm J, Vindeløv L, Garred P: Association of HMGB1 polymorphisms with outcome in patients with systemic inflammatory response syndrome. Crit Care 2008, 12:R83.

2. Goodwin GH, Sanders C, Johns EW: A new group of chromatin-associated proteins with a high content of acidic and basic amino acids. Eur J Biochem 1973, 38:14-19.

3. Javaherian K, Liu JF, Wang JC: Nonhistone proteins HMG1 and HMG2 change the DNA helical structure. Science 1978, 199: $1345-1346$.

4. Wang HC, Bloom $\mathrm{O}$, Zhang $\mathrm{MH}$, Vishnubhakat JM, Ombrellino $\mathrm{M}$, Che JT, Frazier A, Yang H, lvanova S, Borovikova L, Manogue KR, Faist $E$, Abraham $E$, Andersson J, Andersson U, Molina PE, Abumrad NN, Sama A, Tracey KJ: HMG-1 as a late mediator of endotoxin lethality in mice. Science 1999, 285:248-251.

5. Scaffidi P, Misteli T, Bianchi ME: Release of chromatin protein HMGB1 by necrotic cells triggers inflammation. Nature 2002, 418:191-195.

6. Lotze MT, Tracey KJ: High-mobility group box 1 protein
(HMGB1): nuclear weapon in the immune arsenal. Nat Rev Immunol 2005, 5:331-342.

7. Dumitriu IE, Baruah $\mathrm{P}$, Manfredi AA, Bianchi ME, Rovere-Querini P: HMGB1: guiding immunity from within. Trends Immunol 2005, 26:381-387.

8. Bianchi ME, Manfredi AA: High-mobility group box 1 (HMGB1) protein at the crossroads between innate and adaptive immunity. Immunol Rev 2007, 220:35-46.

9. Klune JR, Dhupar R, Cardinal J, Billiar TR, Tsung A: HMGB1: endogenous danger signaling. Mol Med 2008 [Epub ahead of print].

10. Yang H, Ochani M, Li J, Qiang X, Tanovic M, Harris HE, Susarla SM, Ulloa L, Wang $H$, DiRaimo R, Czura CJ, Wang $H$, Roth J, Warren HS, Fink MP, Fenton MJ, Andersson U, Tracey KJ: Reversing established sepsis with antagonists of endogenous high-mobility group box 1. Proc Natl Acad Sci USA 2004, 101:296-301.

11. Chorny A, Delgado M: Neuropeptides rescue mice from lethal sepsis by down-regulating secretion of the late-acting inflammatory mediator high mobility group box 1. Am J Pathol 2008, 172:1297-1307.

12. Hatada T, Wada H, Nobori T, Okabayashi K, Maruyama $K$, Abe $Y$, Uemoto S, Yamada S, Maruyama I: Plasma concentrations and importance of high mobility group box protein in the prognosis of organ failure in patients with disseminated intravascular coagulation. Thromb Haemost 2005, 94:975-979.

13. Sunden-Cullberg J, Norrby-Teglund A, Treutiger CJ: The role of high mobility group box-1 protein in severe sepsis. Curr Opin Infect Dis 2006, 19:231-236.

14. Karlsson S, Pettila V, Tenhunen J, Laru-Sompa R, Hynninen M, Ruokonen E: HMGB1 as a predictor of organ dysfunction and outcome in patients with severe sepsis. Intensive Care Med 2008, 34:1046-1053.

15. Andrassy M, Volz HC, Igwe JC, Funke B, Eichberger SN, Kaya Z, Buss S, Autschbach F, Pleger ST, Lukic IK, Bea F, Hardt SE, Humpert PM, Bianchi ME, Mairbaurl $H$, Nawroth PP, Remppis A, Katus HA, Bierhaus A: High-mobility group box-1 in ischemiareperfusion injury of the heart. Circulation 2008, 117:32163226. 